\title{
Deteksi helicobacter pylori pada plak gigi dengan reverse transcription- polymerase chain reaction
}

\author{
Irene E. Riuwpassa, * St. Rafiah,** I Wayan S.A.*** \\ *Bagian Oral Biologi Fakultas Kedokteran Gigi Universitas Hasanuddin \\ **Bagian Anatomi Fakultas Kedokteran Universitas Hasanuddin \\ ****Dinas Kesehatan Provinsi Sulawesi Selatan \\ Makassar, Indonesia
}

\begin{abstract}
Helicobacter pylori have been found associated with dental plaque. It was suggested that the oral environment may be one of the many potential pathways for their transmission. The aim of this study was to evaluate whether the oral cavity is a potential reservoir and possible sanctuary for Helicobacter pylori. Supragingival and subgingival plaques were analyzed by a Helicobacter genus-specific reverse transcriptase-fragment was identified.
\end{abstract}

Key word: H. pylori, dental plaque, RT-PCR

\begin{abstract}
ABSTRAK
Belum lama ini, Helicobacter pylori ditemukan telah diketahui berkaitan dengan plak gigi. Ditunjukkan bahwa lingkungan oral mungkin merupakan satu dari banyak jalur transmisi yang potensial. Tujuan dari penulisan karya ilmiah ini, adalah untuk mengkaji apakah rongga mulut merupakan suatu reservoir yang potensial dan memungkinkan untuk Helicobacter pylori, plak supragingival dan plak subgingival dianalisis dengan suatu reverse transcriptase-polymerase chain reaction.
\end{abstract}

Kata kunci: H.pylori, plak gigi, RT-PCR

Koresponden: Irene E. Riuwpassa, Bagian Oral Biologi, Fakultas Kedokteran Gigi Universitas Hasanuddin, Jl. Perintis Kemerdekaan Km.10, Tamalanrea, Makassar, Indonesia.

\section{PENDAHULUAN}

Ulkus peptikum adalah suatu daerah ekskoriasi mukosa yang disebabkan oleh kerja pencernaan cairan lambung. Penyebab umum dari ulserasi peptikum adalah ketidakseimbangan antara kecepatan sekresi cairan lambung dan derajat perlindungan yang diberikan oleh sawar mukosa gastroduodenal juga netralisasi asam lambung oleh cairan duodenum.

Salah satu penyebab khusus ulkus peptikum pada manusia adalah infeksi bakteri Helicobacter pylori (H. pylori). Dalam 5 tahun terakhir ini, paling sedikit $75 \%$ penderita ulkus peptikum telah ditemukan menderita infeksi kronis bagian pyloric gastrica dan pada pangkal mukosa duodenum oleh bakteri H. pylori.

Di negara berkembang, prevalensi infeksi mungkin $80 \%$ atau bahkan lebih. Meskipun banyak aspek epidemiologi infeksi H. pylori telah diketahui, cara penyebarannya masih belum jelas. Baru-baru ini, H. pylori ditemukan berhubungan dengan plak gigi. Hal ini menunjukkan bahwa lingkungan oral mungkin merupakan satu dari berbagai jalur transmisi potensial. 
Mikrobiologi dari plak gigi sangatlah kompleks, rapuh dan tidak memiliki bentuk. Dari penelitian sebelumnya, telah diidentifikasi organisme gram-negatif banyak mendominasi pada poket periodontal yang dalam dan saluran akar. Sejumlah asaccharolitic gram-negatif berbentuk batang termasuk Eikenella corrodens, spesies Vibrio anaerob dan spesies Campylobacter lain selain Campylobacter sputorum telah diidentifikasi pada plak gigi.

Infeksi H. Pylori secara fakta sulit dihapuskan dan telah dipostulatkan bahwa terdapat suatu tempat berlindung yang memungkinkan mereka untuk menghindari terapi anti mikroba. Kemajuan dari polymerase chain reaction (PCR) telah menyederhanakan perkembangan tes sensitivitas dan spesivitas untuk mendeteksi mikroorganisme karena hanya membutuhkan sejumlah kecil DNA/RNA. Dengan demikian perlu dilakukan deteksi H. pylori pada plak gigi dan mempelajari apakah kavitas oris berfungsi sebagai reservoir potensial untuk H. pylori.

\section{TINJAUAN PUSTAKA}

\section{Helicobacter pylori}

Helicobacter pylori (H. pylori) berupa batang gram negatif yang berbentuk spiral. Organisme ini berhubungan dengan gastritis antral, penyakit ulkus duodenum (peptik) dan mungkin ulkus gaster, dan karsinoma. ${ }^{1}$

Ciri-ciri organisme ini ialah memiliki banyak flagel pada satu ujung dan bergerak dengan aktif. H.pylori tumbuh secara optimal pada $\mathrm{pH}$ 6,0-7,0 dan akan mati atau tidak tumbuh pada $\mathrm{pH}$ di dalam lumen lambung. ${ }^{2}$

$$
\text { Mekanisme bagaimana H. pylori }
$$
menyebabkan peradangan dan kerusakan mukosa belum dapat dipastikan. Bakteri menginvasi selsel epitel permukaan pada batas-batas tertentu. Toksin dan lipopolisakarida dapat merusak sel-sel mukosa, dan dibentuk amonia oleh aktivitas urease yang secara langsung merusak sel-sel juga. ${ }^{1}$ Tanda dan gejalanya berkaitan dengan gastritis dan penyakit ulkus duodenum. Banyak pasien dengan infeksi H. pylori bersifat asimtomatik. ${ }^{2}$

Pasien yang terinfeksi dengan H.pylori membentuk respons antibodi IgM terhadap infeksi. Selanjutnya dihasilkan IgG dan IgA yang akan menetap, baik secara sistemik maupun pada mukosa dalam titer yang tinggi pada orang-orang yang terinfeksi secara kronik. Pengobatan antimikroba secara dini terhadap infeksi $\mathrm{H}$. pylori menumpulkan respons antibodi, pasien diduga sebagai subjek untuk infeksi berulang. ${ }^{2,3}$

H.pylori terdapat pada mukosa lambung pada kurang dari $20 \%$ orang-orang berusia di bawah 30 tahun tetapi prevalensinya meningkat pada 40$60 \%$ orang-orang berusia 60 tahun. Riwayat alami infeksi H. pylori tidak dapat dipastikan, tetapi rupanya infeksi hanya sekali didapat kemudian menetap selama bertahun-tahun atau sepanjang hidup. ${ }^{1}$

\section{Plak gigi}

Plak gigi didefinisikan kumpulan bakteri pada gigi atau struktur lain dalam rongga mulut. Di dalam $1 \mathrm{~mm}^{3}$ plak gigi dengan berat kira-kira 1 mg mengandung lebih dari $10^{8}$ bakteri. Plak gigi tidaklah keras, tidak termineralisasi bagi bakteri dan terdiri dari glikoprotein polimer. Plak melekat pada gigi maupun prostesis intra oral, dapat menyebabkan karies dan juga penyakit periodontal jika tidak dihilangkan dengan prosedur oral hygiene yang benar. ${ }^{4,5}$

Ketika gigi erupsi, selaput (pellicle) terdapat pada permukaan gigi. Perlekatan mikroorganisme pada permukaan gigi terjadi melalui peranan komponen saliva glikoprotein pada selaput luar tersebut. Saat mikroorganisme melekat pada permukaan mulut yang sesuai, maka 
perkembangan dan pertumbuhannya akan segera terjadi. ${ }^{5}$

\section{Polymerase chain reaction (PCR)}

Sejak pertama kali diperkenalkan pada tahun 1985, teknologi PCR telah menghasilkan terobosan-terobosan besar dalam penelitian dan pengembangan kesehatan dan kedokteran untuk memahami berbagai patogenesis maupun diagnosis penyakit. Perkembangan biologi molekuler menjadi semakin cepat dan hingga saat ini berbagai teknik yang memanfaatkan teknologi PCR tersebut telah banyak dilahirkan. Teknik ini ditemukan tahun 1980 oleh Dr. Kary B. Mullis, warga negara Amerika yang mendapatkan hadiah Nobel pada tahun 1993 untuk bidang Kedokteran. Temuan Mullis bisa dikatakan terobosan di bidang biologi molekuler, karena dengan metode ini para ahli dapat membuat replikasi DNA di dalam tabung reaksi. Perkembangannya yang luar biasa membuat proses karakterisasi dan pembandingan materi genetika baik dari manusia, hewan maupun organisme lain seperti bakteri, virus, tumbuhan dan lainnya berlangsung sangat cepat. ${ }^{6}$

Teknologi PCR merupakan metode enzimatik in vitro yang dipergunakan untuk menghasilkan gugus DNA yang spesifik dalam jumlah besar dan dalam waktu yang singkat. Konsep teknologi ini berkembang dari pemahaman terhadap proses replikasi DNA. Penggunaannya yang semakin luas telah membawa dampak besar bagi pendekatan biologi molekul terhadap berbagai masalah kesehatan dan kedokteran seperti, kelainan genetik, penyakit infeksi, penyakit keganasan, penyakit degeneratif, kedokteran kehakiman dan evolusi serta perkembangan. ${ }^{7,8}$

Untuk menangani penyakit baru, diperlukan diagnosis yang akurat sehingga dapat dibedakan dengan penyakit lain. Diagnosis yang akurat ini sangat diperlukan untuk pemberian obat dan perawatan yang tepat. Ada beberapa cara untuk mendiagnosis suatu penyakit, antara lain isolasi agen penyebab penyakit tersebut dan analisis morfologinya, deteksi antibodi yang dihasilkan dari infeksi dengan teknik enzym-linked immunosorbent assay (ELISA), dan deteksi gen dari agen pembawa penyakit tersebut dengan polymerase chain reaction ( $\mathrm{PCR}$ ).

Teknik yang banyak dan lazim dipakai saat ini adalah teknik PCR, suatu cara sederhana, praktis dan cepat untuk memperbanyak rangkaian DNA spesifik yang diinginkan dengan ukuran tertentu memulai mekanisme perubahan suhu. Prinsip dasar dari metode ini adalah amplifikasi materi genetik yang terkandung dalam setiap organisme hidup. Teknik PCR dapat dilakukan dalam waktu kurang dari satu hari dan jutaan DNA bisa berhasil dibuat. Karena DNA setiap organisme adalah spesifik, maka dengan menggunakan teknik ini dapat diidentifikasi secara akurat organisme asalnya.

Jumlah sampel yang diperlukan untuk dapat dianalisis dengan PCR adalah sangat sedikit. Hanya menggunakan setetes darah, sehelai rambut atau cuplikan spesimen. Hal ini dimungkinkan karena mesin PCR adalah mesin yang dapat menfotokopi dari satu molekul DNA menjadi jutaan, sehingga dengan jumlah sampel yang sangat sedikit, sampel diamplifikasi untuk mencapai jumlah yang dapat dianalisis.

Yang penting dalam teknik PCR adalah desain primer untuk amplifikasi DNA yang memerlukan data sekuen dari agen genom yang bersangkutan. Untuk agen yang mempunyai genom RNA, harus dilakukan reverse transcription (proses sintesis DNA dari RNA) terlebih dahulu dengan menggunakan enzim reverse transcriptase. Setelah DNA diperoleh baru dilakukan dengan PCR. Reverse transcription dan PCR ini bisa 
dilakukan dan biasanya disebut RT-PCR, teknik PCR ini bersifat kualitatif. ${ }^{8}$

\section{Prinsip Teknik PCR}

Prinsip PCR dapat dijelaskan sebagai berikut, pada suhu $94-95^{\circ} \mathrm{C}$, DNA mengalami denaturasi (pembelahan untai ganda menjadi untai tunggal), jika suhunya diturunkan sampai $36-72^{\circ} \mathrm{C}$ maka primer, molekul DNA untai tunggal yang pendek akan menempel pada DNA yang telah terbelah pada tempat yang spesifik (annealing). Selanjutnya, apabila suhu dinaikkan lagi sampai $72^{\circ} \mathrm{C}$, maka primer dengan bantuan DNA polymerase akan membentuk untai DNA sesuai dengan urutan DNA yang telah terbelah (polimeralisasi/elongasi).

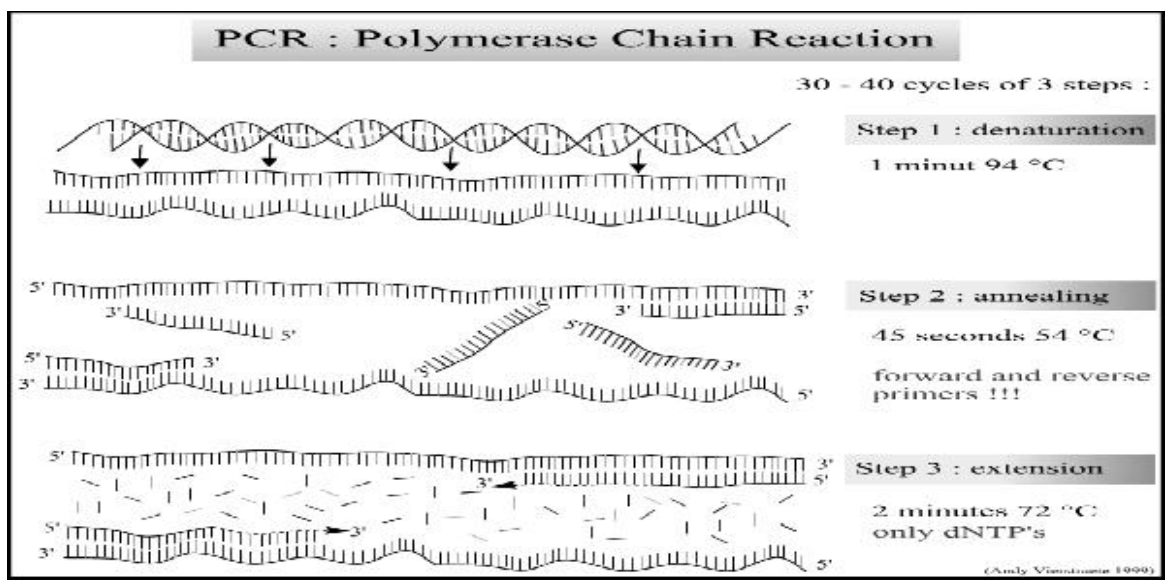

Gambar 1. Tahapan dalam PCR (Sumber: Ansubel F, Donald MC. Short protocols in molecular biology: the polymerase chain reaction. $3^{\text {rd }}$ ed. St Louis: John Wiley and Sons, Inc,; 1995.

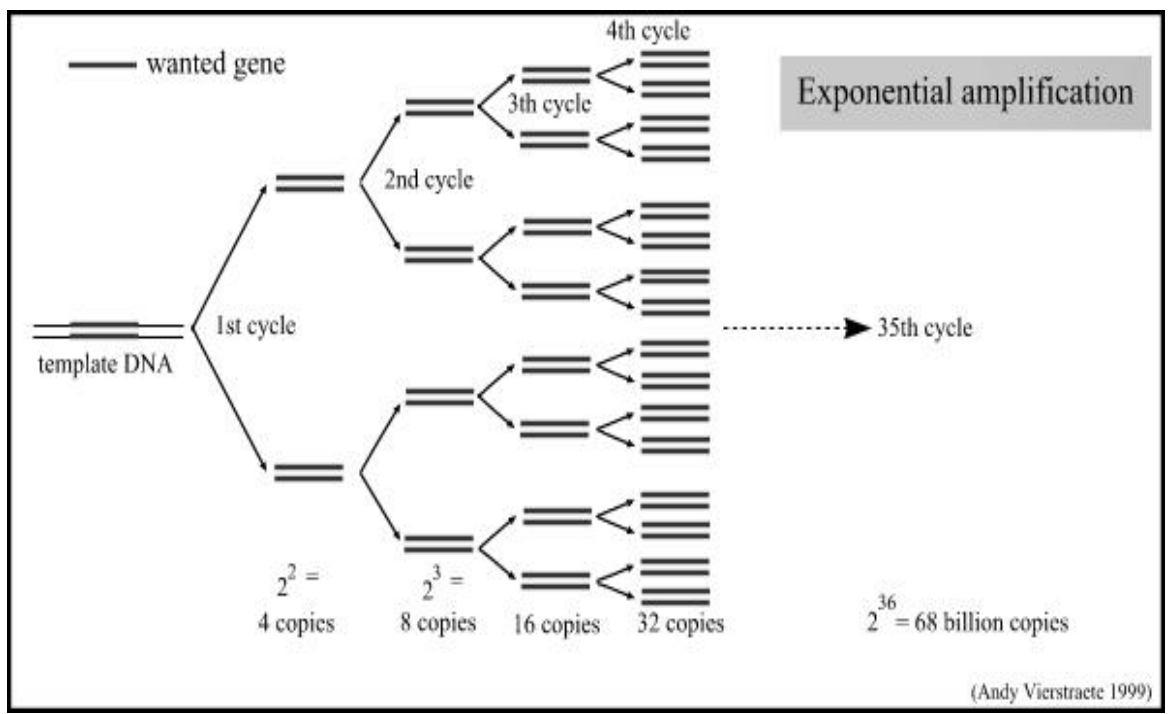

Gambar 2. Eksponensial amplifikasi gen pada PCR. (Sumber: Ansubel F, Donald MC. Short protocols in molecular biology: the polymerase chain reaction. $3^{\text {rd }}$ ed. St Louis: John Wiley and Sons, Inc,; 1995. 
Ketiga tahapan tersebut di atas adalah siklus termal. Jumlah DNA yang dihasilkan adalah $2^{\mathrm{n}}$ (n merupakan banyaknya siklus termal). Rumus tersebut di atas berasal dari penambahan jumlah keeping (copy) DNA eksponensial, keeping DNA yang terbentuk menjadi cetakan bagi reaksi selanjutnya. Banyak siklus yang dilakukan tergantung kepada banyaknya produk PCR yang diinginkan. ${ }^{6,9}$

\section{Pereaksi PCR}

Pereaksi yang digunakan dalam proses PCR adalah DNA cetakan hasil isolasi, primer, enzim Taq Polymerase, dNTPs (deoxynucleosida trifosfat) sebagai sumber nukleotida dan buffer PCR. ${ }^{6}$

\section{Deteksi dan analisis hasil PCR}

Hasil PCR dapat dilihat dengan melakukan elektroforesis pada gel agarose. Elektroforesis merupakan metode standar untuk memisahkan dan mengidentifikasi fragmen DNA sesuai dengan ukurannya. Prinsip dasarnya adalah jika molekul DNA yang bermuatan negatif ditempatkan pada penghantar listrik (buffer), molekul tersebut akan bergerak menuju ke muatan positif. Molekul DNA yang berukuran kecil akan bergerak lebih cepat daripada yang berukuran besar. Ukuran fragmen DNA hasil elektroforesis dapat diketahui dengan menggunakan penanda ukuran (marker) yang salah satunya didapat dari lambda yang telah dipotong oleh enzim restriksi.

Selanjutnya untuk dapat melihat dan menganalisis hasil elektroforesis, DNA di dalam gel agarose diwarnai (staining) dengan menggunakan ethidium bromide (EtBr) yaitu zat pewarna yang dapat berfluoresensi di bawah sinar ultraviolet. Ethidium bromide dapat menyisip di antara basa-basa DNA serta membuat rantai DNA menjadi kaku. DNA hasil amplifikasi tampak sebagai pita yang jelas dan terang apabila gel agarose yang membawa DNA tersebut ditempatkan di atas sinar ultraviolet. ${ }^{6,9}$

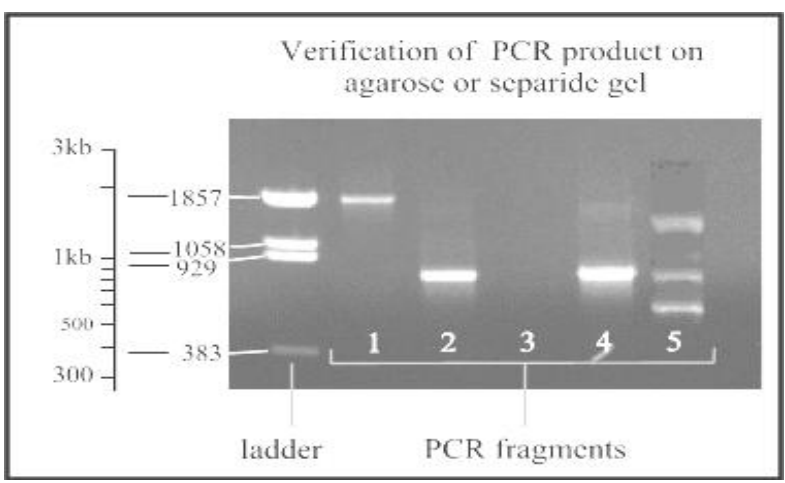

Gambar 3. Produk PCR pada Gel Agarose. (Sumber: Ansubel F, Donald MC. Short protocols in molecular biology: the polymerase chain reaction. $3^{\text {rd }}$ ed. St Louis: John Wiley and Sons, Inc,; 1995.

\section{Jenis PCR}

Ada beberapa macam PCR, berdasarkan jenis dan kegunaannya, yaitu multiplex PCR, RFLPPCR (Restriction Fragment Length Polymorphism), Long Distance PCR, AP-PCR Genom (Arbitrarily Primed-PCR), Deteksi Target RNA, RT-PCR (Reverse TranscriptionPCR/Transkripsi balik), QC-PCR (Quantitative Comparative-PCR), dan Nested amplification.

Multiplex PCR menggunakan beberapa pasang primer yang spesifik untuk target yang berbeda pada suatu amplifikasi DNA yang sama. Koamplifikasi ini mempunyai beberapa tujuan, yaitu dapat mendeteksi adanya kelainan pada sekwens DNA yang panjang, dapat menguji segmen dari target genom yang tidak terkait, sebagai kontrol internal, dan untuk uji multi patogen dari spesimen tunggal, dengan biaya lebih murah. Sebagai contoh dari multiplex PCR adalah deteksi gen yang spesifik terhadap toksin Staphylococcus aureus dan Clostridium difficile 
dan koamplifikasi kontrol internal secara kompetitif.

Restriction fragment length polymorphism merupakan jenis PCR yang mendeteksi mutasi yang terdapat pada genom DNA. Teknik ini mampu mengamplifikasi DNA termasuk urutan yang termutasi dengan menggunakan apitan primer dan diikuti enzim restriksi terhadap produk PCR.

Long distance PCR merupakan jenis PCR yang berguna untuk mengamplifikasi dan mendeteksi produk PCR dengan ukuran $50 \mathrm{~kb}$ atau lebih.

AP-PCR Genom (Arbitrarily Primed-PCR) merupakan jenis PCR yang dapat digunakan untuk mendeteksi polimorfisme sehubungan dengan pemetaan gen, filogenetik dan populasi biologi.

Deteksi Target RNA merupakan PCR yang digunakan untuk mendeteksi ekspresi gen yang berbeda dan dapat langsung diklon dengan mengisolasi produk amplifikasi. Template RNA dapat dideteksi dengan PCR jika ekstrak RNA terlebih dahulu diubah menjadi c-DNA dengan menggunakan enzim reverse transcriptase.

RT-PCR (reverse transcription$\mathrm{PCR} /$ transkripsi balik) berguna untuk mendeteksi dan mengamplifikasi RNA.

QC-PCR (quantitative comparative-PCR), menggunakan tambahan eksogen internal. Tambahan tersebut terdiri dari fragmen DNA yang pada ke-2 sisinya terdapat urutan DNA target dan urutan primer spesifik.

Nested amplification. Salah satu modifikasi PCR yang popular adalah PCR yang menggunakan nested sets primer dan dikenal sebagai nested amplification. Dalam suatu protokol nested amplification, pada putaran pertama amplifikasi digunakan sepasang primer dan amplifikasi dilakukan sebanyak 15-30 siklus. Produk dari amplifikasi putaran pertama ini dipindahkan ke tabung lain dan PCR ke dua dijalankan dengan menggunakan sepasang primer yang spesifik terhadap internal sequence dari produk PCR yang dihasilkan pada putaran pertama. PCR putaran ke dua ini juga dilakukan sebanyak 15-30 siklus, kemudian produk dari PCR putaran ke dua ini dideteksi dengan menggunakan elektroforesis gel. Keuntungan dari nested amplification ini, yaitu memberikan sensitivitas yang sangat tinggi. Kadang tanpa hibridisasi dengan menggunakan probe, single copy dari target dapat terdeteksi. Dengan mentransfer produk PCR putaran pertama ini, mengencerkan inhibitor yang mungkin ada pada sampel awal. ${ }^{8,10}$

\section{PEMBAHASAN}

\section{Reverse transcription-PCR untuk mendeteksi H. pylori pada plak gigi}

Beberapa teknik berdasarkan asam nukleat telah dikembangkan untuk mendeteksi H. pylori. Amplifikasi invitro dari segmen gen ribosomal $16 \mathrm{~S}$ memiliki keuntungan secara teoritik karena tingginya jumlah copy rRNA per sel bakteri meningkatkan copy DNA target beberapa ribu kali lipat. Karenanya reverse transcription (RT) dari RNA yang diikuti oleh PCR menawarkan keuntungan teoritik sensitivitas dan spesivitas yang tinggi bila dikombinasikan dengan Southernhybridisasi dan deteksi menggunakan suatu probe amplifikasi PCR untuk deteksi hasil reaksi. ${ }^{11,12}$

\section{Prosedur Laboratoris}

Pada prosedur di laboratorium, diawali dengan pengambilan spesimen. Gingiva dan plak pasien diambil menggunakan plak indices dari Silness dan Loe. Indeks gingival sebagai berikut, $0=$ Normal, 1 = Oedem ringan, dengan tidak ada perdarahan pada saat probing, 2 = Inflamasi sedang, kemerahan, oedem dan perdarahan saat probing, dan $3=$ Inflamasi berat, oedem dan 
kemerahan, ulserasi dan kecenderungan untuk perdarahan spontan.

Sedangkan indeks plak adalah $0=$ Tidak ada plak, 1 = Selapis tipis plak, terlihat hanya pada saat pengambilan (probing) dengan sistem indikator warna, 2 = Akumulasi sedang, dari deposit di dalam poket atau margin dilihat dengan mata biasa, dan $3=$ Akumulasi berat dari material yang mengisi antara margin gingival dan permukaan gigi, daerah interdental terisi oleh debris.

Plak diangkat dari permukaan gigi menggunakan kuret periodontal steril, baik plak supra maupun sub gingival dikumpulkan dengan scrape ke atas melawan permukaan gigi. Sampel plak ditempatkan pada agar Brucella H. Pylori steril yang mengandung $20 \%$ gliserol dan disimpan pada suhu $-70{ }^{\circ} \mathrm{C}$ hingga diproses.

Pada penanganan sampel, sampel dipindahkan ke microcentrifuge dengan pipet plastik steril yang sekali pakai. Bahan plak ini akan dikumpulkan dengan cara disentrifugasi pada suhu $4{ }^{0} \mathrm{C}$ selama 10 menit. Supernatant dituangkan dan presipitasi homogen dengan pestle homogenizer (Kontes, Vinelan,N.J.). Homogen dihentikan dan di-vortex dalam $200 \mu$ lysis buffer $(10 \mathrm{mM}$ Tris $\mathrm{HCl}, 1 \mathrm{mM}$ EDTA pH 8,0, $10 \mathrm{mM} \mathrm{NaCl}, 1 \%$ Triton X-100). Setelah diinkubasikan selama 10 menit pada suhu $100{ }^{0} \mathrm{C}$, ekstraksi sampel sekali lagi di-vortex dengan volume $(24: 1 ; \mathrm{vol} / \mathrm{vol})$ dalam Phase Lock Gel tube. Setelah 15 menit disentrifus, lapisan atas cairan akan berisi asam nukleat dan disimpan pada suhu $-20{ }^{0} \mathrm{C}$ setelah digunakan. ${ }^{11}$

Selanjutnya pada tahap RT-PCR, disiapkan 2 primer oligonukleotida dengan urutan HP1 (5' TGGCAATCAGCGTCAGGTAATG - 3 ') dan HP2 (5 ' - GCTAAGAGATCAGCCTATGTCC 3 ') berasal dari H. pylori 16S rRNA. Reagen RTPCR dari volume total $30 \mu 1$ mengandung buffer PCR (50 mmmmM KCl, 10mM Tris $\mathrm{HCl}$ (pH8.0),
2,5 $\mathrm{mM} \mathrm{MgCl}_{2}, 3 \%$ glycerol, 4 deoxynucleotida (dATP, dCTP, dTTP, dGTP masing masing 200 $\mu \mathrm{M}), 180$ ng primer HP1, 40 unit Rnase (Promega Biotec, Madison, Wis), $100 \mathrm{U}$ mouse mammary leukemia virus reverse transcriptase (GIBCO BRL) dan $10 \mu \mathrm{l}$ ekstraksi asam nukleat. Setelah inkubasi selama 60 menit dengan suhu $37^{\circ} \mathrm{C}$, total volume $70 \mu \mathrm{l} \mathrm{PCR}$ buffer, $180 \mathrm{ng}$ primer HP2 dan 2,5 U AmpliTaq polymerase. Setiap reaksi ditutupi mineral oil $50 \mu \mathrm{l}$ untuk mencegah evaporasi. Reaksi pencampuran merupakan awal dari tahap denaturasi pada suhu $94{ }^{\circ} \mathrm{C}$ selama 5 menit, diikuti 39 siklus amplifikasi dalam program kontrol suhu (mesin thermal cycler), denaturasi 1 menit pada suhu $94^{\circ} \mathrm{C}$, annealing 1 menit suhu $55^{\circ} \mathrm{C}$ dan extension primer 3 menit $70^{\circ} \mathrm{C}$. Setelah 39 kali siklus, tahap extension akan berlanjut lagi 10 menit dengan suhu $72^{\circ} \mathrm{C}$ dan produk disimpan pada suhu $4^{\circ} \mathrm{C}$ hingga digunakan. Digunakan masing-masing 20 $\mu 1$ hasil amplifikasi dan dianalisis dengan ethidium bromide $0,5 \mu \mathrm{g}$ per $\mathrm{ml}$ yang digunakan sebagai penanda (stain). ${ }^{11}$

\section{Elektroforesis $^{13}$}

Tahap elektroforesis akan melalui empat tahap. Pertama, pembuatan gel, ditimbang 2 gr agarose dan dilarutkan dalam $100 \mathrm{ml}$ TBE buffer $1 \mathrm{x}$ untuk mendapatkan larutan agarose $2 \%$, campuran agarose dan TBE buffer 1x dipanaskan hingga larut kemudian ditunggu hingga agak dingin kemudian ditambah $15 \mu$ l SybrSafe, dan larutan agarose dituang ke dalam cetakan dan ditunggu hingga beku.

Kedua, pemmbuatan DNA marker, sebanyak $25 \mu 1$ DNA 100 bp ladder dimasukkan ke dalam tube berisi $1 \mathrm{ml}$ Blue Juice Loading Dye dan dicampur untuk marker, lalu label tube dilepaskan dan diganti menjadi marker.

Ketiga, persiapan running electroforesis, gel yang telah beku dimasukkan ke dalam alat 
elektroforesis dan direndam dalam larutan TBE 1x, lalu sebanyak $20 \mu \mathrm{l}$ amplicon (hasil amplifikasi) ditambah dengan $1 \mu$ l Blue Juice Loading Dye (tanpa marker) dicampur dan dimasukkan ke dalam sumur-sumur gel sebanyak $15 \mu 1$, dan terakhir marker dimasukkan ke dalam sumur di dekat kontrol positif.

Yang teakhir, keempat adalah running electroforesis, elektroforesis dihidupkan dan dijalankan dari muatan negatif (katode) ke muatan positif (anode) pada 100A dan 40 menit, setelah elektroforesis akan terlihat pita yang terbentuk. Apabila pita sejajar dengan kontrol positif berarti hasil positif.

\section{Manfaat pemeriksaan genetis dibandingkan teknik konvensional}

Dibandingkan dengan teknik konvensional, teknik genetis mempunyai beberapa keunggulan, antara lain dapat dilakukan langsung pada bahan pemeriksaan tanpa terlebih dahulu melalui proses isolasi bakteri sehingga dapat mempercepat hasil pemeriksaan, dan karena tidak memerlukan pembiakan bakteri, teknik ini akan lebih aman bagi petugas dari kemungkinan terjadinya infeksi laboratorik. ${ }^{14}$

\section{SIMPULAN}

Helicobacter pylori merupakan organisme gram negatif, microaerophilic spiral yang berhubungan erat dengan gastritis aktif dan kronik sebagaimana dengan penyakit ulkus peptic dan ulkus duodenal. Infeksi $\mathrm{H}$. pylori terdapat di seluruh dunia. Meskipun banyak aspek epidemiologi infeksi H. pylori telah diketahui, model transmisinya masih belum jelas. Dengan ditemukan adanya hubungan antara $\mathrm{H}$ pylori dengan plak pada gigi menunjukkan bahwa lingkungan oral mungkin merupakan salah satu jalur transmisi potensial. Kemajuan PCR telah menyederhanakan perkembangan tes sensitivitas dan spesifitas untuk mendeteksi mikroorganisme dengan hanya membutuhkan sejumlah kecil DNA/RNA. Beberapa teknik berdasarkan asam nukleat telah dikembangkan untuk mendeteksi $\mathrm{H}$. pylori. Untuk menyelidiki apakah kavitas oris merupakan suatu reservoir yang potensial dan memungkinkan untuk $H$. pylori, plak supra dan sub gingival dapat dianalisis dengan suatu RTPCR spesifik genus H. pylori 16S RNA.

\section{DAFTAR PUSTAKA}

1. Brooks GF, Butel SJ, Morse SA. Mikrobiologi kedokteran. Penerjemah dan Editor. Bagian Mikrobiologi Fakultas Kedokteran Universitas Airlangga. Jakarta: Salemba Medika; 2001.

2. Guyton, Hall. Fisiologi kedokteran. Alih bahasa: Setiawan I, editor. Ed.9. Jakarta: EGC; 1997.

3. Price SA, Wilson LM. Patofisiologi. Alih bahasa: Brahm. Jakarta: EGC; 2005.

4. Lindhe J. Textbook of clinical periodontology. Copenhagen: Munksgaard; 1988.

5. Gebara ECE, Pannuti C, Faria CM. Prevalence of Helicobacter pylori detected by polymerase chain reaction in the oral cavity of periodontitis patients. Oral Microbiol Immunol 2004; 19 (4): 277-80.

6. Powledge TM. The polymerase chain reaction; 2005.

7. Mullis K. Specific enzymatic amplification of DNA in vitro: the polymerase chain reaction. Cold Spring Harbor Symp Quant Biol 1986; 51: 335-50.

8. Yuwono T. Teori dan aplikasi polymerase chain reaction. Yogyakarta: ANDI; 2006.

9. Ansubel F, Donald MC. Short protocols in molecular biology: the polymerase chain reaction, $3^{\text {rd }}$ ed. St. Louis: John Wiley and Sons, Inc,; 1995.

10. Putra ST. Biologi molekuler kedokteran. Surabaya: Airlangga University Press; 1997.

11. Nguyen AMH, Engstrand L, Genta RM. Detection of Helicobacter pylori in dental plaque by reverse transcription-polymerase 
chain reaction. J Clin Microbiol 1992; 31: 783-7.

12. Umeda M, Kobayashi H, Hayashi J. High prevalence of Helicobacter pylori detected by PCR in the oral cavities of periodontitis patients. J Periodontol 2003; 74: 129-34.
13. Departemen Kesehatan Republik Indonesia. Badan Penelitian dan Pengembangan Kesehatan.

14. Sjahrurachman A. Cara Genetis untuk Menentukan Kepekaan Bakteri Terhadap Antibiotika. Medika 2000; 26 (1) Januari. 